Gut, 1971, 12, 27-33

\title{
Small intestinal bacterial flora and folate status in gastrointestinal disease
}

\author{
A. V. HOFFBRAND, SOAD TABAQCHALI, C. C. BOOTH, AND D. L. MOLLIN \\ From the Departments of Haematology and Medicine and the MRC Malabsorption Research Group, \\ Royal Postgraduate Medical School, and the Department of Haematology, St Bartholomew's Hospital, \\ London
}

SUMMARY Serumfolate levels and the bacteriology of the small intestine were studied in 13 patients with jejunal diverticulosis, 29 patients with partial gastrectomy, and five patients with ileal disease. The mean serum folate level in the patients with partial gastrectomy $(7 \cdot 2 \mathrm{~m} \mu \mathrm{g} / \mathrm{ml})$ was similar to that of control subjects but the mean level in the patients with jejunal diverticulosis $(14.6 \mathrm{~m} \mu \mathrm{g} / \mathrm{ml})$ was significantly higher than the mean level of the control group $(8.0 \mathrm{~m} \mu \mathrm{g} / \mathrm{ml})$. Five of the 13 patients with jejunal diverticulosis and two of the patients with partial gastrectomy had levels above the upper limit of the control group ( $>16.6 \mathrm{~m} \mu \mathrm{g} / \mathrm{ml}$ ), and five of six patients with jejunal diverticulosis studied excreted raised amounts of folate in the urine $(>13.2 \mu \mathrm{g}$ in 24 hours). Serum folate in one of these patients with jejunal diverticulosis was identified chromatographically as 5-methyltetrahydrofolic acid. The mean serum folate level $(9.0 \mathrm{~m} \mu \mathrm{g} / \mathrm{ml})$ in the patients with partial gastrectomy who had Esch. coli in the jejunal aspirates was significantly higher than in those without Esch. coli present (mean $4.2 \mathrm{~m} \mu \mathrm{g} / \mathrm{ml}$ ). It is suggested that in gastrointestinal disease jejunal bacteria may contribute to the serum folate level even though this remains in an accepted normal range.

Some patients had low serum folate levels despite having a large number of Esch. coli in the jejunum. No evidence of malabsorption of folic acid was found in three such patients even though one had lactobacilli capable of consuming folate in the jejunum.

No relationship was found between serum folate level and ileal bacteriology.

It is well recognized that in patients with the intestinal stagnant-loop syndrome faecal microorganisms in the lumen of the small intestine may cause vitamin $B_{12}$ deficiency by interfering with the absorption of dietary vitamin $B_{12}$. The relationship between the presence of these microorganisms and folate status in such patients is still uncertain. Some workers (Badenoch, Bedford, and Evans, 1955; Watkinson, Feather, Marson, and Dossett, 1959; Cooke, Cox, Fone, Meynell, and Gaddie, 1963; Barrett and Holt, 1967) have suggested that these microorganisms may cause folate deficiency by interfering with the absorption of dietary folate. Hoff brand, Tabaqchali, and Mollin (1966), on the other hand, reported that faecal microorganisms in the upper small intestine may contribute to the body's folate stores by synthesizing folate within the lumen of the small intestine which is then absorbed.

Received for publication 21 September 1970.
The present paper reports the results of a study of patients following partial gastrectomy, with jejunal diverticulosis, and with ileal disease, in whom the relation of serum folate level to the number, type, and distribution of bacteria in the small intestine is examined. In addition, the results of chromatographic studies to identify the form of folate circulating in patients with the intestinal stagnant-loop syndrome are reported.

\section{Subjects Studied}

The series included 25 healthy adult subjects, 29 patients with partial gastrectomy for benign peptic ulcer, including 17 who had undergone a Billroth I operation and 12 who had had the Polya type of operation. None of these patients had clinical or radiological evidence of small intestinal disease. There were 13 patients with multiple jejunal diverticulosis and five patients 
with ileal disease, three of whom had radiological evidence of Crohn's disease; the remaining two had had an ileal resection for Crohn's disease.

All these patients had normal serum vitamin $B_{12}$ levels or were receiving regular maintenance vitamin $B_{12}$ therapy at the time of this study.

\section{Methods}

SERUM AND URINARY FOLATE LEVELS These were measured by microbiological assay using Lactobacillus casei as described by Waters and Mollin (1961). Random 24-hour urine samples were collected into bottles containing $2 \mathrm{~g}$ of ascorbic acid for the urine folate estimations.

\section{FOLIC ACID ABSORPTION}

This was measured by the method of Chanarin, Anderson, and Mollin (1958) in which the patient receives an oral dose of folic acid $(40 \mu \mathrm{g} / \mathrm{kg}$ body weight) after saturation with parenteral folic acid and the rise in serum folic acid concentration is determined microbiologically using Streptococcus faecalis as test organism. In normal subjects the peak rise is greater than $40 \mathrm{~m} \mu \mathrm{g} / \mathrm{ml}$.

BACTERIAL PRODUCTION OR UTILIZATION OF FOLATE

The method used has been previously described (Hoffbrand et al, 1966). Essentially, bacteria were allowed to grow in vitro in a serum of measured folate ( $L$. casei) content. At the end of the incubation period (usually 24 hours) the bacteria were removed by centrifugation and the folate content of the supernatant serum was measured again using $L$. casei.

\section{BACTERIOLOGICAL STUDIES}

Jejunal intubations were carried out on fasting subjects using a sterile open-ended tube. The tube was allowed to pass to the ileum in the five patients with ileal disease. The identification of bacteria was carried out by standard methods (Wilson and Miles, 1964) and quantitative bacterial counts were performed using the serial dilution method of Miles, Misra, and Irwin (1938). Anaerobic bacterial cultures were carried out as described by Gorbach, Nahas, Lerner, and Weinstein (1967).

\section{CHROMATOGRAPHY OF SERUM FOLATE}

Serum was diluted 1:5 in 0.02 Msodium-phosphate buffer, $p H 6 \cdot 1$, containing $200 \mathrm{mg}$ ascorbic acid per $100 \mathrm{ml}$ and extracted by autoclaving at $121^{\circ} \mathrm{C}$ for two and a half minutes. Coagulated proteins were separated by centrifugation and the clear supernatant was applied to a column $(20 \times 0.8 \mathrm{~cm})$ of DEAE cellulose previously equilibrated with $0 \cdot 02 \mathrm{M}$ phosphate buffer, $p \mathrm{H} 7 \cdot 0$. The folate derivatives were eluted by a linear gradient of increasing phosphate concentration $(p \mathrm{H} 7 \cdot 0)$ from $0.02 \mathrm{M}$ to $0.5 \mathrm{M}$. Both buffers contained $0.2 \%$ mercapto-ethanol and eluted fractions of $5 \mathrm{ml}$ were collected into tubes containing $0.1 \mathrm{ml}$ of $1 \%$ (w/v) ascorbic acid. The folate content of each tube was measured microbiologically with L.casei.

The following substances were also chromatographed: $\left({ }^{14} \mathrm{C}\right)$ labelled 5 methyltetrahydrofolic acid (5(methyl $\left.{ }^{14} \mathrm{C}\right) \mathrm{H}_{4}$ Pte Glu), $\left({ }^{3} \mathrm{H}\right)$ labelled folic acid $\left(\left({ }^{3} \mathrm{H}\right)\right.$ Pte $\left.\mathrm{Glu}\right)$, and pteroyltriglutamic acid (Pte $\left.\mathrm{Glu}_{3}\right)$.

\section{Results}

\section{SERUM FOLATE LEVELS}

The serum folate levels in the control subjects and in the patients with partial gastrectomy, jejunal diverticulosis, and ileal disease are shown in Figure 1. In the control subjects, the serum folate levels ranged from 3.0 to $16.6 \mathrm{~m} \mu \mathrm{g} / \mathrm{ml}$ (mean $8.0 \mathrm{~m} \mu \mathrm{g} / \mathrm{ml}$ ). Of the 29 patients with partial gastrectomy, two had serum folate levels above the upper limit of the control group, but the mean serum folate level of the 29 patients $(7 \cdot 2 \mathrm{~m} \mu \mathrm{g} / \mathrm{ml})$ was not significantly different from that of the control subjects. On the other hand, of the 13 patients with jejunal diverticulosis as many as five had serum folate levels above the upper limit of the control group and the mean serumfolate level

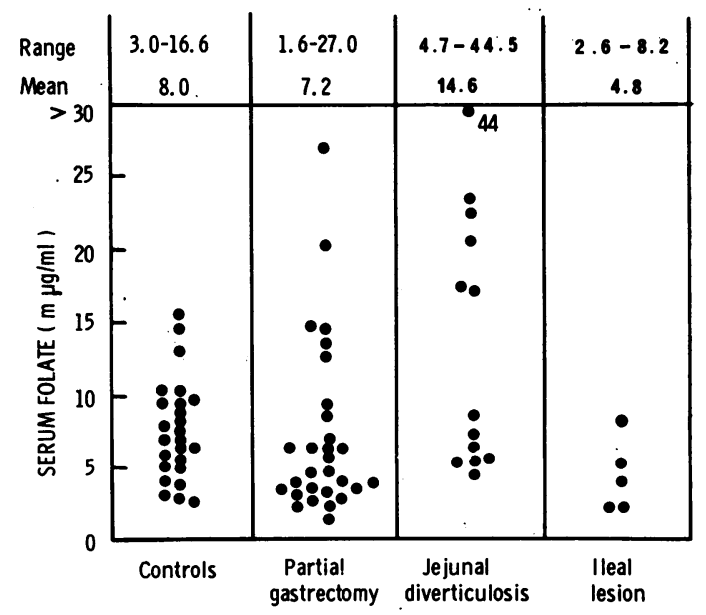

FIG. 1. The serum folate levels of the control subjects and of patients after partial gastrectomy, with jejunal diverticulosis, and with an ileal lesion. 
of these 13 patients $(14.6 \mathrm{~m} \mu \mathrm{g} / \mathrm{ml})$ was significantly greater than that of the control group $(P<0.01)$. None of the five patients with ileal disease had a raised serum folate level and their mean serum folate level was only $4.8 \mathrm{~m} \mu \mathrm{g} / \mathrm{ml}$.

URINARY FOLATE EXCRETION IN PATIENTS WITH JEJUNAL DIVERTICULOSIS

The 24-hour urine folate excretions in 10 of the normal subjects ranged from 0.7 to $13.2 \mu \mathrm{g}$ (mean $7.0 \mu \mathrm{g}$ ). Five of six patients with jejunal diverticulosis tested excreted more than $13.2 \mu \mathrm{g}$ of folate in 24 hours and the mean excretion among the six patients, $24.9 \mu \mathrm{g}$ in 24 hours, was significantly raised $(\mathrm{P}<0.01)$ (Table $I)$.

\begin{tabular}{|c|c|c|c|c|c|}
\hline \multicolumn{3}{|c|}{ Control Subjects } & \multicolumn{3}{|c|}{ Jejunal Diverticulosis } \\
\hline Subject & $\begin{array}{l}\text { Serum } \\
\text { Folate } \\
(m \mu g / m l)\end{array}$ & $\begin{array}{l}\text { Urine } \\
\text { Folate } \\
(\mu g / 24 h r)\end{array}$ & Patient & $\begin{array}{l}\text { Serum } \\
\text { Folate } \\
(m \mu g / m l)\end{array}$ & $\begin{array}{l}\text { Urine } \\
\text { Folate } \\
(\mu g / 24 h r)\end{array}$ \\
\hline $\begin{array}{r}1 \\
2 \\
3 \\
4 \\
5 \\
6 \\
7 \\
8 \\
9 \\
10\end{array}$ & $\begin{array}{r}13.6 \\
6.0 \\
8.1 \\
5.3 \\
4.2 \\
3.4 \\
8.6 \\
3.2 \\
6.6 \\
5.3\end{array}$ & $\begin{array}{r}13.2 \\
11.1 \\
11.0 \\
10.4 \\
6.5 \\
6.4 \\
6.2 \\
3.7 \\
1.1 \\
0.7\end{array}$ & $\begin{array}{l}1 \\
2 \\
3 \\
4 \\
5 \\
6\end{array}$ & $\begin{array}{r}10.1 \\
17.6 \\
8.8 \\
9.0 \\
16.8 \\
5.6\end{array}$ & $\begin{array}{r}47.4 \\
37.5 \\
21 \cdot 3 \\
19.4 \\
16.1 \\
7.5\end{array}$ \\
\hline Mean & $6 \cdot 4$ & $7 \cdot 0$ & & $11 \cdot 3$ & 24.9 \\
\hline
\end{tabular}

Table I The serum folate levels and 24-hour urine folate excretions of 10 randomly selected control subjects and six patients with jejunal diverticulosis

RELATION OF SERUM FOLATE LEVELS TO JEJUNAL BACTERIOLOGY

All the patients with jejunal diverticulosis had Esch. coli present in the jejunal aspirates in concentrations ranging from $10^{4}$ to $10^{9}$ organisms per $\mathrm{ml}$. In patients following partial gastrectomy there was a striking difference in the serum folate level according to whether or not Esch. coli were present in the jejunal fluid (Fig. 2). Among the 11 patients without Esch. coli present, there was only a narrow range in serum folate level (from 2.2 to $6.3 \mathrm{~m} \mu \mathrm{g} / \mathrm{ml}$, mean $4.2 \mathrm{~m} \mu \mathrm{g} / \mathrm{ml}$ ) whereas there was a wide range in the serum folate levels (from 1.6 to $27.0 \mathrm{~m} \mu \mathrm{g} / \mathrm{ml}$ ) of the 18 patients who had had a gastrectomy, in whom Esch. coli were present in the jejunal fluid. The mean level of $9.0 \mathrm{~m} \mu \mathrm{g} / \mathrm{ml}$ was significantly higher than that of the group without Esch. coli $(\mathrm{P}<0 \cdot 01)$. Nevertheless, there were three patients with Esch. coli present who had serum folate levels below the lower limit of the control range $(<3.0 \mathrm{~m} \mu \mathrm{g} / \mathrm{ml})$.
The relation between the serum folate levels of the patients with partial gastrectomy and jejunal diverticulosis and their quantitative counts of Esch. coli in the jejunal fluid is shown in Figure 3. There was no direct correlation, though high serum folate levels tended to occur only in patients with high counts of Esch. coli. A few patients, however, had low normal or subnormal serum folate levels despite having high counts of Esch. coli. Further studies were performed on these particular patients in an attempt to clarify the relationship between their serum folate levels and their jejunal bacteria.

FURTHER STUDIES IN PATIENTS WITH LOW SERUM FOLATE LEVELS AND HIGH JEJUNAL Esch. coli COUNTS

\section{Absorption of folic acid}

Folic acid absorption studies were carried out in three of these patients in order to determine

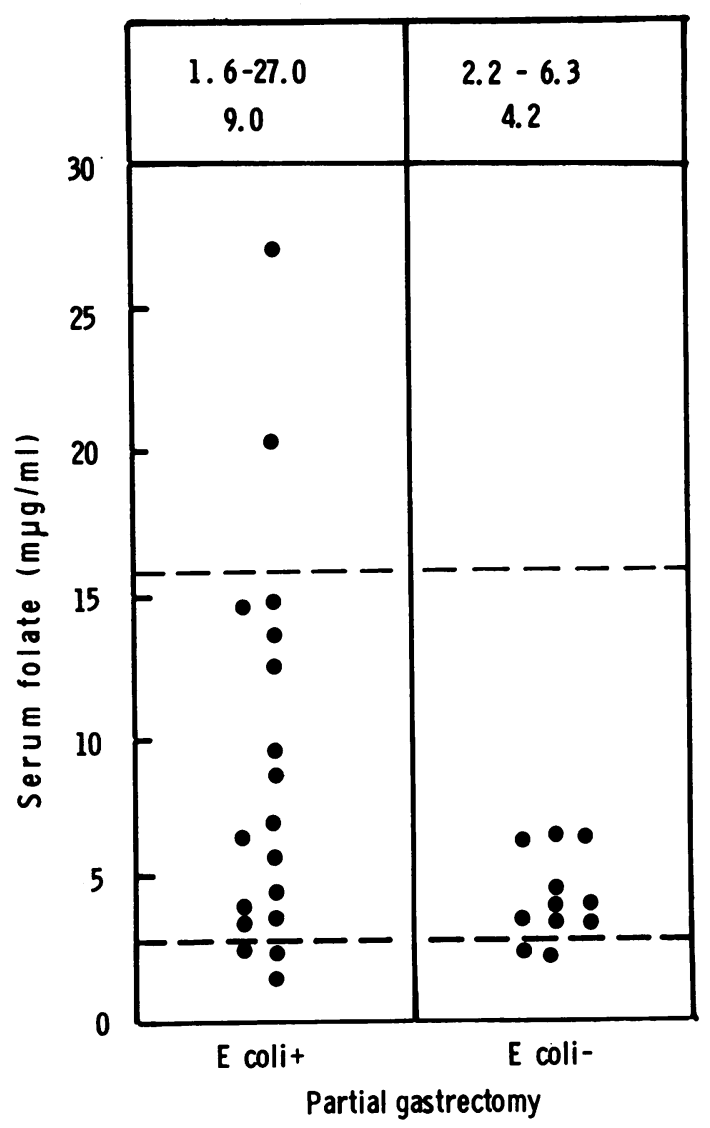

FIG. 2. The serum folate levels in the patients after gastrectomy divided according to whether or not Esch. coli. were present in the jejunal aspirate. 


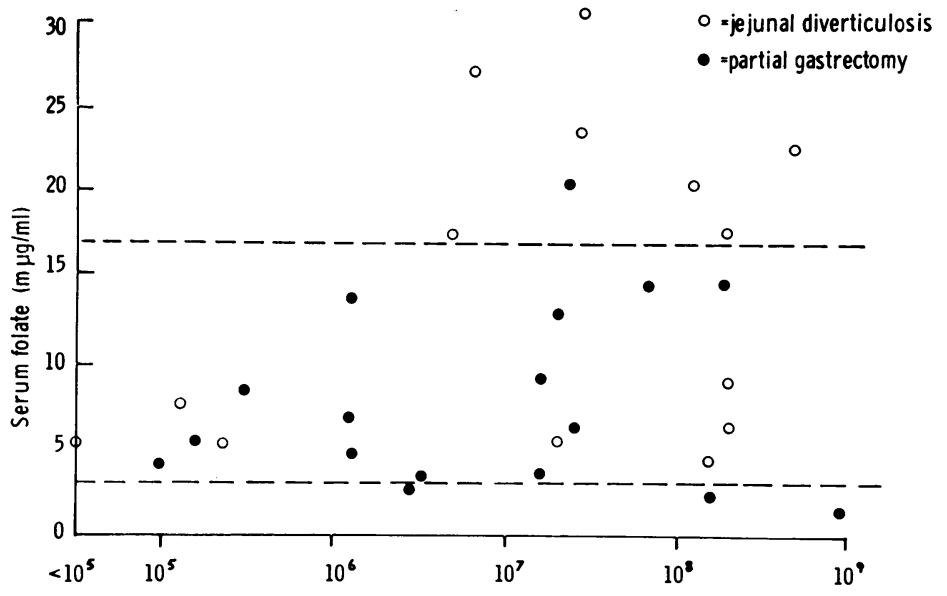

FIG. 3. The serum folate levels in the patients after gastrectomy and with jejunal diverticulosis related to the quantitative Esch. coli counts in the jejunal aspirate.

Esch. coli $/ \mathrm{ml}$ of jejunal fluid

whether the low serum folate levels could be attributed to malabsorption of folate. The results are shown in Table II. Folic acid absorption was normal in all three patients and the absorption did not change significantly in one patient after treatment with broad-spectrum antibiotics

\begin{tabular}{|c|c|c|c|c|c|c|}
\hline \multicolumn{2}{|c|}{ Case Diagnosis } & \multirow{2}{*}{$\begin{array}{l}\text { Serum } \\
\text { Folate } \\
\text { Level } \\
(m \mu g / m l)\end{array}$} & \multirow[t]{2}{*}{$\begin{array}{l}\text { Jejunal } \\
\text { Bacteriology } \\
\text { (count/ml juice) }\end{array}$} & \multicolumn{3}{|c|}{$\begin{array}{l}\text { Folic Acid } \\
\text { Absorption } \\
(m \mu g / m l)\end{array}$} \\
\hline & & & & 01 & 2 & 3 \\
\hline \multirow[t]{2}{*}{1} & $\begin{array}{l}\text { Partial } \\
\text { gastrectomy }\end{array}$ & $1 \cdot 6$ & $\begin{array}{l}\text { Esch. coli } \\
\left(1 \times 10^{9}\right)\end{array}$ & & 81 & $50^{1}$ \\
\hline & & & $\begin{array}{l}\text { Lactobacilli } \\
\quad\left(1 \times 10^{7}\right)\end{array}$ & 167 & 42 & $33^{2}$ \\
\hline 2 & $\begin{array}{l}\text { Partial } \\
\text { gastrectomy }\end{array}$ & $2 \cdot 3$ & $\begin{array}{c}\text { Esch. coli } \\
\left(2 \times 10^{8}\right)\end{array}$ & 161 & 75 & 30 \\
\hline 3 & $\begin{array}{l}\text { Jejunal } \\
\text { diverticulosis }\end{array}$ & $4 \cdot 7$ & $\begin{array}{l}\text { Esch. coli } \\
\quad\left(2 \times 10^{8}\right)\end{array}$ & 0112 & 101 & 80 \\
\hline
\end{tabular}

Table II The serum folate levels, jejunal bacteriology, and absorption of folic acid in two patients following partial gastrectomy and one patient with jejunal diverticulosis

${ }^{1}$ Before antibiotic therapy.

${ }^{2}$ After antibioitic therapy. (tetracycline $1 \mathrm{~g}$ daily in divided doses for seven days) which reduced the jejunal bacterial counts from $10^{9}$ to $10^{3}$ organisms $/ \mathrm{ml}$.

\section{BACTERIAL FOLATE PRODUCTION AND UTILIZATION in vitro}

The jejunal bacteria from one of these patients (case 1, Table II) were cultured and tested for folate production and utilization in vitro. The principal organisms isolated were Esch. coli $\left(10^{9} / \mathrm{ml}\right)$ which were found to produce folate, and a Lactobacillus $\left(10^{8} / \mathrm{ml}\right)$ which consumed folate (Table III). A third organism frequently found in high concentrations in the jejunal juice of the patients with the intestinal stagnant-loop syndrome was bacteroides. This organism, isolated from a patient with jejunal diverticulosis and a high serum folate level, like Esch. coli, synthesized folate (Table III).

\section{RELATION OF SERUM FOLATE LEVEL TO ILEAL BACTERIOLOGY}

High Esch. coli counts in the ileum, unlike high counts of Esch. coli in the jejunum, did not appear to be associated in any patient with a raised

\begin{tabular}{|c|c|c|c|c|c|c|c|}
\hline \multirow{2}{*}{\multicolumn{2}{|c|}{ Case }} & \multirow[t]{2}{*}{ Organism } & \multicolumn{3}{|l|}{ Incubation } & \multicolumn{2}{|c|}{ Free Folate Activity $(m \mu \mathrm{g} / \mathrm{ml})$} \\
\hline & & & Medium & Time $(h r)$ & Atmosphere & Before & After \\
\hline 1 & Partial gastrectomy & $\begin{array}{l}\text { Esch. coli } \\
\text { Lactobacilli }\end{array}$ & $\begin{array}{l}\text { Serum } \\
\text { Lactobacilli broth } \\
\text { Lactobacilli broth }+\end{array}$ & $\begin{array}{l}24 \\
24\end{array}$ & $\begin{array}{l}\text { Aerobic } \\
\text { Aerobic }\end{array}$ & $\begin{array}{l}0 \cdot 2 \\
2 \cdot 4\end{array}$ & $\begin{array}{l}7 \cdot 5 \\
1 \cdot 4\end{array}$ \\
\hline 4 & Jejunal diverticulosis & $\begin{array}{l}\text { Esch. coli } \\
\text { Bacteroides }\end{array}$ & $\begin{array}{l}\text { pteroylglutamic acid } \\
\text { Serum } \\
\text { Serum }\end{array}$ & $\begin{array}{l}24 \\
24 \\
48\end{array}$ & $\begin{array}{l}\text { Anaerobic } \\
\text { Aerobic } \\
\text { Anaerobic }\end{array}$ & $\begin{array}{r}21 \cdot 8 \\
0 \cdot 8 \\
1 \cdot 1\end{array}$ & $\begin{array}{l}1 \cdot 5 \\
3 \cdot 2 \\
5 \cdot 0\end{array}$ \\
\hline
\end{tabular}

Table III The production and utilization of (L. casei active) folate by the jejunal bacteria of one patient following partial gastrectomy (case 1, Table II) and one patient with jejunal diverticulosis 


\begin{tabular}{|c|c|c|c|c|}
\hline Case & Diagnosis & $\begin{array}{l}\text { Serum } \\
\text { Folate } \\
\text { Level } \\
(m \mu g / m l)\end{array}$ & $\begin{array}{l}\text { Jejunal } \\
\text { Bacteriology } \\
\text { (Esch. coli } \\
\text { count/ml juice) }\end{array}$ & $\begin{array}{l}\text { Ileal } \\
\text { Bacteriology } \\
\text { (Esch. coli } \\
\text { count/ml juice) }\end{array}$ \\
\hline 5 & Resection & $8 \cdot 2$ & $10^{\circ}$ & $10^{\circ}$ \\
\hline 6 & $\begin{array}{l}\text { Crohn's } \\
\text { disease }\end{array}$ & 5.9 & $10^{5}$ & $10^{8}$ \\
\hline 7 & Resection & 4.4 & $\mathbf{0}$ & $10^{\circ}$ \\
\hline 8 & $\begin{array}{l}\text { Crohn's } \\
\text { disease }\end{array}$ & $2 \cdot 7$ & 0 & $10^{\circ}$ \\
\hline 9 & $\begin{array}{l}\text { Crohn's } \\
\text { disease }\end{array}$ & $2 \cdot 6$ & 0 & $4.5 \times 10^{7}$ \\
\hline
\end{tabular}

Table IV The serum folate levels and Esch. coli counts in jejunal and ileal aspirates from the five patients with ileal lesions

serum folate level (Table IV). In the five patients in: whom ileal intubations were carried out, the counts ranged from $4.5 \times 10^{7}$ to $1 \times 10^{9} / \mathrm{ml}$ but the serum folate levels were all in the low normal or subnormal range.
IDENTIFICATION OF SERUM FOLATE IN A PATIENT WITH JEJUNAL DIVERTICULOSIS Figure 4 compares the elution pattern after DEAE column chromatography of serum folate from a patient with jejunal diverticulosis and raised serum folate level with that of a normal subject, and with the elution pattern of standard marker solutions of 5-methyltetrahydrofolate, pteroyltriglutamic acid, and pteroylglutamic acid. The serum from both subjects showed a single peak, microbiologically active for $L$. case $i$ and not for $S$. faecalis, which coincided with the peak of radioactivity after chromatography of radioactive 5-methyltetrahydrofolic acid. No other folate compounds were detected in the sera.

\section{Discussion}

The results of these studies confirm previous

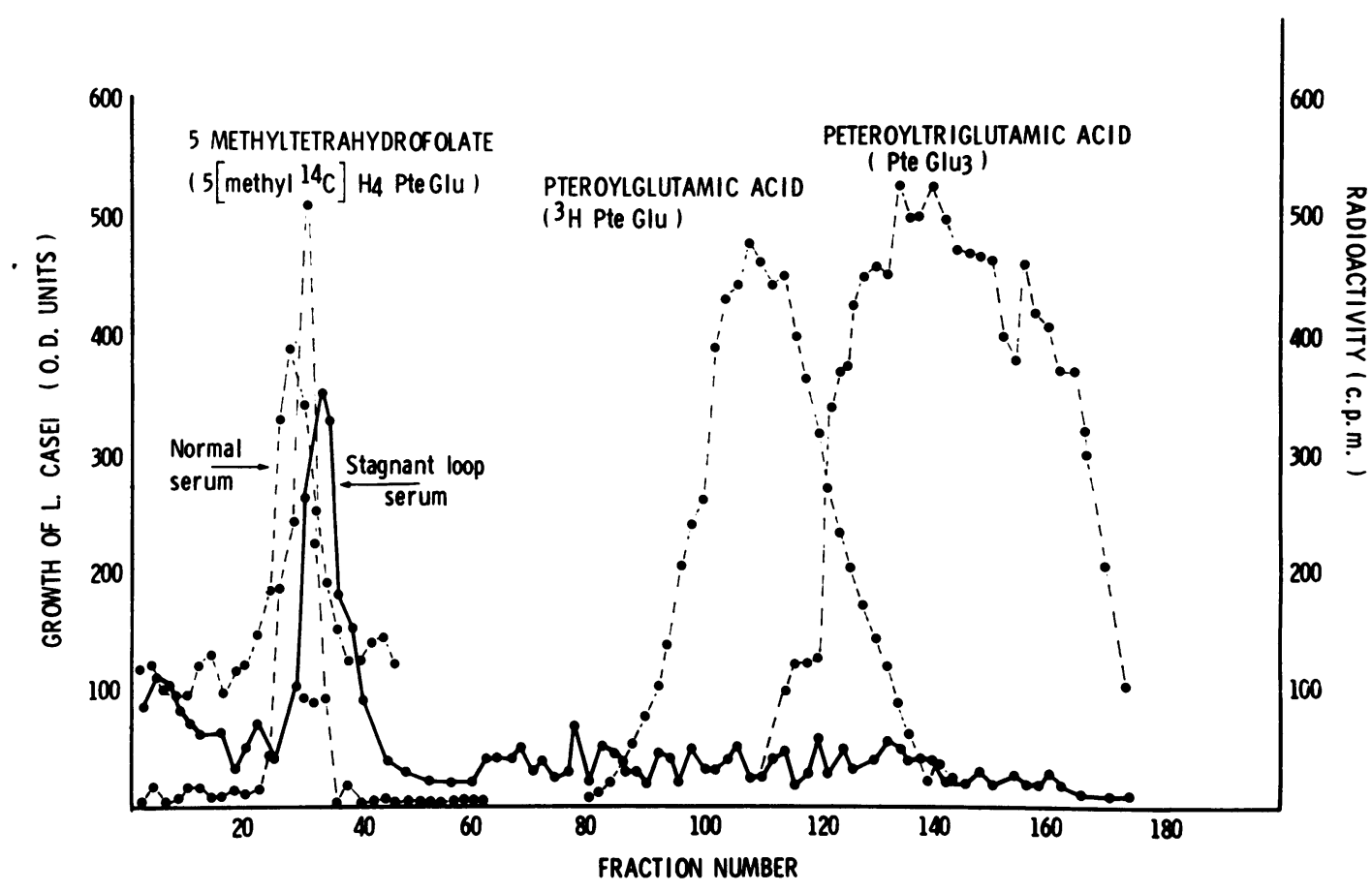

FIG. 4. The results of DEAE column chromatography of serum folate from a normal subject and from a patient with the stagnant-loop syndrome due to jejunal diverticulosis compared with solutions of radioactive 5 methyltetrahydrofolate, radioactive folic acid (pteroylglutamic acid), and non-radioactive pteroyltriglutamic acid. The activities of the nonradioactive compounds in the different fraction numbers are expressed in terms of growth of $\mathrm{L}$. casei (measured turbidimetrically) whereas the activities of the radioactive compounds are expressed as counts per minute (measured in an Intertechnique liquid scintillation counter). 
observations (Hoffbrand et al, 1966) that high serum folate levels may be found in some patients with faecal bacteria in their upper small intestine. They also show that raised urine folate excretion occurs in such patients. This is consistent with the theory that these high serum folate levels are dise to excess production of folate by the intestinal bacteria and not to reduced urinary excretion of the vitamin.

Normal serum folate has been identified as 5-methyltetrahydrofolic acid (Herbert, Larrabee, and Buchanan, 1962). Previous studies have shown that the folate compound in the serum of patients with the intestinal stagnant loop syndrome is active for $L$. casei but not for $S$. faecalis (Hoffbrand et al, 1966). This suggested that the compound was either a pteroyltriglutamate or 5-methyltetrahydrofolate. The present studies show that in a patient with jejunal diverticulosis and a raised serum folate level, the folate compound circulating behaves chromatographically as well as microbiologically as 5-methyltetrahydrofolate.

The present studies also show that faecal bacteria in the jejunum may contribute to the patient's serum folate level even though this remains within an accepted normal range, a phenomenon previously suggested by Klipstein and Samloff (1966). The evidence for this is as follows: $50 \%$ of postgastrectomy patients with Esch. coli organisms in the jejunum had serum folate levels in a normal range but above the upper limit of the serum folate in those postgastrectomy patients without Esch. coli, and the mean serum folate in those with bacteria was significantly higher than in those without.

There was a poor correlation both in patients with a partial gastrectomy and in patients with jejunal diverticulosis between quantitative counts of Esch. coli in the jejunum and serum folate level but there are several possible reasons for this. It may be that the bacterial count does not give an accurate estimate of the total number of bacteria in the jejunum. Also different strains of Esch. coli may synthesize folate at different rates (Klipstein and Lipton, 1970). Moreover, microorganisms other than Esch. coli may be involved in folate synthesis, for instance bacteroides which may be present in very high concentrations in some patients with thestagnant-loop syndrome. Indeed, other organisms present may, as shown here, consume folate. The patient's dietary folate intake may also profoundly affect the serum folate level. Finally, the height of the serum folate level may not be a good indication of the total folate produced by the bacteria since the rate of clearance of folate from plasma may well vary from one patient to the next, and indeed in the small number of patients studied here, there was a poor correlation between serum folate and urine folate excretion.

A few of the patients studied here with large numbers of faecal bacteria in the jejunum had extremely low serum folate levels. Barret and Holt (1966) reported one such patient and suggested that jejunal bacteria interfered with folic acid absorption, since in their patient folic acid absorption, initially subnormal, improved after antibiotic therapy. Wakisaka (1968) also found malabsorption of folic acid in four patients with the intestinal blind-loop syndrome which improved to normal after antibiotic therapy. In one patient studied here organisms (lactobacilli) were present in the jejunum which were capable of consuming folic acid in vitro. In the three patients with high Esch. coli counts and subnormal serum folate levels studied here, however, including the patient in whom lactobacilli capable of consuming folate were demonstrated, folic acid absorption tests were normal and in one patient folic acid absorption was not altered by antibiotic therapy. These findings do not exclude the possibility that bacteria in these patients interfere with the absorption of dietary folate, since the amount of folic acid used to test absorption was unphysiological and may have 'swamped' the bacteria. Moreover, food folate consists mainly of pterotypolyglutamates, not of folic acid, and it will therefore be necessary to test the absorption of a physiological dose of pteroylpolyglutamates in such patients before a firm conclusion can be reached on this point.

Finally, the present results show that bacteria in the distal small intestine do not affect folate status. This is not surprising since folate is poorly absorbed from the ileum in man (Hepner, Booth, Cowan, Hoffbrand, and Mollin, 1968).

We are very grateful to Dr S. L. Gorbach for carrying out the anaerobic cultures, to Dr K. Parsa for assistance with the chromatographic studies, to Dr M. Sarner, Royal Portsmouth Hospital for providing a number of samples from patients with jejunal diverticulosis, and to Dr Jean Cowan and Mr J. Morgan for the microbiological assay results.

$\left({ }^{3} \mathrm{H}\right)$ Labelled folic acid and $\left({ }^{14} \mathrm{C}\right)$ labelled 5 methyltetrahydrofolic acid were obtained from the Radiochemical Centre in Amersham and pteroyltriglutamic acid was given by Professor M. Friedkin. 


\section{References}

Badenoch, J., Bedford, P. D., and Evans, J. R. (1955). Massive diverticulosis of the small intestine with steatorrhoea and megaloblastic anaemia. Quart. J. Med., 34, 321-330.

Barret, C. R.Jr, and Holt, P. R. (1966). Postgastrectomy blind-loop syndrome. Megaloblastic anemia secondary to malabsorption of folic acid. Amer. J. Med., 41, 629-637.

Chanarin, I., Anderson, B. B., and Mollin, D. L. (1958). The absorption of folic acid. Brit. J. Haemat., 4, 156-166.

Cooke, W. T., Cox, E. V., Fone, D. J., Meynell, M. J., and Gaddie, R. (1963). The clinical and metabolic significance of jejunal diverticula. Gut, 4, 115-131.

Gorbach, S. L., Nahas, L., Lerner, P. I., and Weinstein, L. (1967) Studies of intestinal microfiora. I. Effects of diet, age and periodic sampling on numbers of fecal micro-organisms in man. Gastroenterology, 53, 845-855.

Hepner, G. W., Booth, C. C., Cowan, J., Hoffbrand, A. V., and Mollin, D. L. (1968). Absorption of crystalline folic acid in man. Lancet, 2, 302-306.

Herbert, V., Larrabee, A. R., and Buchanan, J. M. (1962). Studies on the identification of a folate compound of human serum J. clin. Invest., 41, 1134-1138.

Hoff brand, A. V., Tabaqchali, S., and Mollin, D. L. (1966). High serum folate levels in intestinal blind-loop syndrome. Lancet, 1, 1339-1342.

Klipstein, F. A., and Lipton, S. D. (1970). Intestinal flora of folate-deficient mice. Amer. J. clin. Nutr., 23, 132-140.

Klipstein, F. A., and Samloff, I. M. (1966). Folate synthesis by intestinal bacteria. Amer. J. clin. Nutr., 19, 237-246.

Miles, A. A., Misra, S. S., and Irwin, J. O. (1938). The estimation of the bactericidal power of blood. J. Hyg.'(Lond.), 38, 732-749.

Wakisaka, G. (1968). Problems in post-operative patients of digestive disease. XI Blind-loop syndrome with megaloblastic anemia. Gastroent. Jap., 3, 109-110.

Waters, A. H., and Mollin, D. L. (1961). Studies on the folic acid activity of human serum. J. clin. Path., 14, 335-344.

Watkinson, G., Feather, D. B., Marson, F. G. W., and Dossett, J. A. (1959). Massive jejunal diverticulosis with steatorrhoea and megaloblastic anaemia improved by excision of diverticula. Brit. med. J., 3, 58-62.

Wilson, G. S., and Miles, A. A. (1964). Topley and Wilson's Principles of Bacteriology and Immunity, 5th Ed. Arnold, London. 